\title{
Hukum dan Teknologi: Model Kolaborasi Hukum dan Teknologi dalam Kerangka Perlindungan Hak Cipta di Internet
}

\author{
Budi Agus Riswandi \\ Fakultas Hukum Universitas Islam Indonesia \\ Jln. Tamansiswa No. 158 Yogyakarta \\ budiagusriswandi@gmail.com
}

\begin{abstract}
The main issues in this research include: first, what the legal issues and cases are related to the protection of copyright on internet? Second, how is the development of the copyright protection recently? Third, is the collaboration of law and technology as the model of copyright protection on internet? This research was conducted by using the normative legal method. The result of the research showed some conclusions: first, the presence of internet has brought a negative impact on the attitude and behavior of human. Such negative impact is reflected with the increasing cases of copyright infringement. Therefore, the issue of copyright protection on internet becomes one of crucial issues. Second, recently, the copyright protection on internet can be done through technology approach or legal approach. If these two approaches are conducted separately, then the copyright protection on internet is found very difficult to be realized. To realize the copyright protection, then the model of the collaboration between the technology approach and legal approach becomes something certain. Third, the instrument of the copyright protection in internet collaborates between the technology and legal approach as seen in the regulation in Article 11 and 18 WIPO Internet Treaties and in some other countries such as United States and Indonesia.
\end{abstract}

Key words: Law, technology, protection, copyright, internet

\begin{abstract}
Abstrak
Pokok permasalahan dalam penelitian ini: pertama, permasalahan dan kasus-kasus hukum apakah yang terkait dengan perlindungan hak cipta di internet? Kedua, bagaimanakah perkembangan perlindungan hak cipta saat ini? Ketiga, apakah kolaborasi hukum dan teknologi merupakan model perlindungan hak cipta di internet? Penelitian disajikan dengan menggunakan metode penelitian hukum normatif. Hasil penelitian menyimpulkan, pertama, kehadiran internet telah membawa dampak negatif kepada sikap dan perilaku manusia. Dampak negatif ini tercerminkan dengan maraknya kasus-kasus pelanggaran hak cipta. Oleh karena itu, masalah perlindungan hak cipta di internet menjadi salah satu isu yang krusial. Kedua, selama ini perlindungan hak cipta di internet dapat dilakukan melalui pendekatan teknologi atau pendekatan hukum. Apabila pendekatan ini dilakukan secara sendiri-sendiri, maka perlindungan hak cipta di internet menjadi sangat sulit diwujudkan. Untuk dapat mewujudkan perlindungan hak cipta di internet, maka model kolaborasi antara pendekatan teknologi dan hukum menjadi suatu keniscayaan. Ketiga, instrumen perlindungan hak cipta di internet mengkolaborasikan antara pendekatan teknologi dan hukum. Hal ini dapat dilihat pada ketentuan Article 11 dan 18 WIPO Internet Treaties dan di beberapa negara lainnya, seperti Amerika Serikat dan Indonesia.
\end{abstract}

Kata-kata kunci: Hukum, teknologi, pelindungan, hak cipta, internet. 


\section{Pendahuluan}

Era globalisasi yang ditandai dengan kehadiran teknologi internet ternyata telah menimbulkan pisau bermata dua dalam bidang hak cipta. Pertama, kehadiran teknologi internet telah mampu meningkatkan upaya publikasi dan diseminasi informasi dan ilmu pengetahuan yang sedemikian banyaknya ke seluruh penjuru dunia. Informasi dan ilmu pengetahuan dapat dinikmati oleh seluruh manusia di muka bumi ini. Kedua, kehadiran teknologi internet telah mendorong maraknya berbagai tindakan/perbuatan yang menimbulkan kerugian dan cenderung melanggar hukum terus meningkat dengan pola yang berkembang.

Kondisi demikian sangatlah mengkhawatirkan karena kehadiran teknologi internet semakin membukakan peluang bagi maraknya tindakan pelanggaran hak cipta. Dalam beberapa jenis ciptaan, semisal musik dan lagu pelanggaran hak cipta jumlahnya sudah sangat memprihatinkan.

Dalam perkembangannya, persoalan pelanggaran hak cipta oleh beberapa ahli di bidang hak cipta dan teknologi informasi diyakini hal tersebut tidak dapat diselesaikan hanya berdasarkan pada satu pendekatan saja. Pelanggaran hak cipta dengan menggunakan teknologi internet akan dapat dikurangi jumlahnya melalui upaya kolaborasi antara pendekatan teknologi (technical approach) dan pendekatan hukum (juridical approach). Untuk dapat memahami wujud kolaborasi keduanya, maka penelitian ini disajikan dalam rangka menguraikan dan membuktikan bahwa hukum dan teknologi saat ini sudah dikolaborasikan dalam rangka perlindungan hak cipta di internet, baik ditingkat global maupun nasional.

\section{Rumusan Masalah}

Penelitian ini disusun berdasarkan rumusan permasalahan sebagai berikut; pertama, permasalahan dan kasus-kasus hukum apakah terkait dengan perlindungan hak cipta di internet? Kedua, bagaimanakah perkembangan perlindungan hak cipta saat ini? dan Ketiga, apakah kolaborasi hukum dan teknologi merupakan model perlindungan hak cipta di internet?

\section{Tujuan penelitian}

Penelitian ini disusun dengan tujuan sebagai berikut; Pertama, mengetahui dan mengidentifikasi permasalahan dan kasus-kasus hukum yang terkait dengan 
perlindungan hak cipta di internet; Kedua, mengetahui dan mendeskripsikan perkembangan perlindungan hak cipta saat ini; dan Ketiga, memformulasikan kolaborasi hukum dan teknologi sebagai model perlindungan hak cipta di internet.

\section{Metode Penelitian}

Penelitian ini merupakan tipe penelitian hukum normatif dengan pendekatan yuridis dan komparatif. Bahan hukum yang digunakan terdiri dari bahan hukum primer dan bahan hukum sekunder. Bahan hukum primer terdiri dari peraturan perundang-undangan, yaitu Undang-Undang No. 19 Tahun 2002 Hak Cipta, UU No. 28 Tahun 2014 tentang Hak Cipta, dan The Digital Millenium Copyright Act of 1998, dan konvensi internasional. Sedangkan bahan hukum sekunder terdiri dari buku, literatur, dokumen, dan jurnal, serta berbagai artikel yang berkaitan dengan penelitian ini. Hasil penelitian yang diperoleh melalui studi kepustakaan ini akan dianalisis data secara deskriptif kualitatif.

\section{Hasil Penelitian dan Pembahasan}

\section{Fenomena dan Kasus-Kasus Hak Cipta di Era Digital}

Banyaknya aktivitas yang menggunakan jasa internet serta komputer yang dilakukan oleh setiap orang, mengakibatkan perlunya memberikan suatu perlindungan terhadap informasi yang ada dalam komputer. Jaringan internet sebagai titik pusat yang menghubungkan segala macam sumber informasi yang dibutuhkan oleh setiap orang sehingga bukan tidak mungkin setiap pelanggaran dan kejahatan akan terjadi melalui dunia maya tersebut. Hak Kekayaan Intelektual hadir dengan berbagai macam perlindungan yang terdapat di dalamnya. Salah satu jenis hak kekayan intelektual yang paling berpengaruh dan berkaitan erat dengan pemanfaatan internet ialah perlindungan hak cipta atas karya digital. Perlindungan hak cipta atas karya digital merupakan pengakuan atas hak eksklusif untuk memberikan insentif bagi pihak pencipta yang mengekspresikannya melalui medium digital. ${ }^{1}$

${ }^{1}$ Konsep ini dipahami dari pendapat Dan L Burk yang menyatakan:” Works of creative authorship have long been subject to ownership under the rubric of copyright law, which offers certain defined exclusive rights as an incentive for creation and publication of expressive works.Dan L. Burk," The Mereology of Digital Copyright," Fordham Intell. Prop. Media \& Ent. L.J. (Vol. 18), hlm. 712. 
Hak cipta semakin penting di kala banyak bermunculan permasalahan perlindungan hak cipta atas karya digital. ${ }^{2}$ Permasalahan perlindungan hak cipta atas karya digital tersebut mencakup pada: Pertama, adanya kemudahan dalam melakukan reflikasi. Dalam konteks ini teknologi digunakan untuk menciptakan dan menggunakan karya digital yang dapat digunakan lagi untuk membuat salinannya secara terus menerus yang hampir mendekati "kesempurnaan." Kedua, adanya kemudahan dalam mentransmisikan dan menggunakan karya digital secara terus menerus. Penyediaan bandwith yang besar semakin berpotensi untuk memfasilitasi dan menyebarluaskan hasil pembajakan karya digital yang beraneka ragam. Ketiga, penggunaan media digital mempermudah dalam memodifikasi dan mengadaptasi karya dalam bentuk digital. Hal ini tentunya dapat berpotensi terjadinya pelanggaran hak cipta, termasuk hak moral. Keempat, adanya kesamaan sifat dari karya-karya dalam bentuk digital, di mana semua karya digital sepertinya sama. Hal ini dapat mendorong untuk mempermudah mengkombinasikan karya digital sehingga menjadi karya baru, seperti karya multimedia. ${ }^{3}$

Emilija Arsenova4, berpandangan bahwa dari sisi teknis fenomena pemanfaatan medium digital telah menjadi persoalan, yakni di satu sisi adanya kepentingan perlindungan hak cipta atas karya digital, akan tetapi di lain pihak telah menciptakan permasalahan perlindungan hak cipta itu sendiri. Salah satunya berupa tindakan perbanyakan karya digital yang dilindungi hak cipta yang tidak dapat dibedakan dengan bentuk orisinalnya (aslinya). Dengan adanya fenomena perbanyakan hak cipta atas karya digital yang tidak dapat dibedakan dengan bentuk orisinalnya, maka hal ini dapat menimbulkan pelanggaran hak cipta atas karya digital, baik hak moral maupun hak ekonomi. ${ }^{5}$

${ }^{2}$ Hak cipta di medium digital saat ini sedang menghadapi suatu tantangan yang sangat serius. Hal ini dibuktikan dengan adanya kebebasan untuk melakukan reproduksi, redistribusi ciptaan dengan sebebas-bebasnya tanpa memperhatikan ketentuan hak cipta. Hal ini disinyalir oleh Jessica Wood sebagai sebuah revolusi hak cipta digital yang menuju kepada era The Darknet. Jessica A. Wood, "The Darknet: A Digital Copyright Revolution," XVI Rich. J.L. \& Tech. 14 (2010), http://jolt.richmond.edu/v16i4/article14.pdf.

${ }^{3}$ Simon Stokes, Digital Copyrights Law and Practice, Butterworths LexisNexis, United Kingdom, 2002, hlm. 10 hlm. 3 .

${ }^{4}$ Emilija Arsenova, “Technical aspects of Digital Rights Management," Seminar: Digital Rights Management,

${ }^{5}$ Hak moral adalah hak-hak yang melindungi kepentingan pribadi si pencipta. Konsep hak moral berasal dari sistem kontinental, yaitu dari Prancis. Menurut konsep hokum continental hak pengarang (droit d'auteur, author rights) terbagi menjadi hak ekonomi untuk mendapatkan keuntungan yang bernilai ekonomi seperti uang, dan hak moral yang menyangkut perlindungan atas suatu reputasi si pencipta. Untuk hak ekonomi diartikan sebagai hak yang dipunyai oleh pencipta untuk mendapatkan manfaat ekonomi. Menurut Djumhana hak ekonomi umumnya 
Sebagai akibat lebih lanjut dari permasalahan hak cipta di internet, maka banyak kasus hak cipta yang telah timbul di masyarakat pengguna internet. Kasuskasus tersebut sebagaimana dapat dikemukakan di bawah ini.

\section{Kasus Pembajakan Software di Jakarta ${ }^{6}$}

Penyidik PPNS Direktorat Jenderal Hak Kekayaan Intelektual bersama BSA (Business Software Association) dan Kepolisian melaksanakan Penindakan Pelanggaran Hak Cipta atas Software di 2 tempat di Jakarta yaitu Mall Ambasador dan Ratu Plasa pada Kamis (5/4). Penindakan di Mall Ambasador dan Ratu Plaza dipimpin langsung oleh IR. Johno Supriyanto, M.Hum dan Salmon Pardede, SH., M.Si dan 11 orang PPNS HKI. Penindakan ini dilakukan dikarenakan adanya laporan dari BSA (Business Software Association) pada 10 Februari 2012 ke kantor Direktorat Jenderal Hak Kekayaan Intelektual yang mengetahui adanya CD Software Bajakan yang dijual bebas di Mall Ambasador dan Ratu Plaza di Jakarta. Dalam kegiatan ini berhasil di sita CD Software sebanyak 10.000 keping dari 2 tempat yang berbeda. CD software ini biasa di jual oleh para penjual yang ada di Mall Ambasador dan Ratu Plasa seharga Rp. 50.000-Rp. 60.000 sedangkan harga asli software ini bisa mencapai Rp. 1.000 .000 per softwarenya. Selain itu, Penggrebekan ini akan terus dilaksanakan secara rutin tetapi pelaksanaan untuk penindakan dibuat secara acak/random untuk wilayah di seluruh Indonesia. Salmon pardede, selaku Kepala Sub Direktorat Pengaduan, Direktorat Jenderal Hak Kekayaan Intelektual, mengatakan bahwa "Dalam penindakan ini para pelaku pembajakan CD Software ini dikenakan Pasal 72 ayat (2) yang berbunyi barang siapa dengan sengaja menyiarkan, memamerkan, mengedarkan, atau menjual kepada umum suatu ciptaan atau barang hasil pelanggaran Hak Cipta atau Hak Terkait sebagaimana dimaksud pada ayat (1) dipidana dengan pidana penjara paling lama 5 tahun dan/atau denda paling banyak Rp. 500.000.000,00

\footnotetext{
di setiap Negara meliputi jenis hak berupa; hak reproduksi atau penggandaan, hak adaptasi, hak distribusi, hak penampilan atau performance right, hak penyiaran atau broadcasting right, hak program kabel, droit de suite, hak pinjam masyarakat atau public lending right. Muhamad Djumhana dan R Djubaedillah, Hak. Milik Intelektual (Sejarah, Teori, dan Praktiknya di Indonesia), Citra Aditya Bakti, Bandung, 1997, hlm. 72. Lihat juga Budi Agus Riswandi dan M Syamsudin, Hak Kekayaan Intelektual dan Budaya Hukum, Rajagrafindo Persada, Jakarta, 2005, hlm. 3-7. Bandingkan dengan AusAID dan ASTP II, "Indonesia Australia Specialised Training Project Phase II,"Short Course in Intellectual Property Rights (Elementry), Conducted by Asian Law Group Pty Ltd., hlm. 68.

${ }^{6}$ http://www.dgip.go.id/penindakan-hak-cipta-atas-software diakses 24 Agustus 2014.
} 
dan tidak menutup kemungkinan dikenakan Pasal 72 ayat (9) apabila dalam pemeriksaan tersangka diketahui bahwa tersangka juga sebagai pabrikan".

Dengan adanya penindakan ini diharapkan kepada para pemilik mall untuk memberikan arahan kepada penyewa counter untuk tidak menjual produk-produk software bajakan karena produk bajakan ini tidak memberikan kontribusi kepada negara dibidang pajak di samping itu untuk menghindari kecaman dari United States Trade Representative (USTR) agar Indonesia tidak dicap sebagai negara pembajak

Kasus Sony Corp Am. v. Universal City Studios, Inc (selanjutnya disebut kasus "Betamax") ${ }^{7}$

Sony menjual alat perekam "Betamax" dan tape yang memungkinkan masyarakat untuk merekam program televisi. Dua petinggi dalam industri konten televisi, Universal City Studios dan Walt Disney Production, segera mengajukan gugatan melawan Sony untuk pelanggaran Hak Cipta sekunder. Universal dan Disney berpendapat bahwa Sony harus bertanggung jawab pada pelanggaran Hak Cipta yang dilakukan oleh konsumen yang memanfaatkan sistem Beta, yang menyebabkan penyalinan sederhana menjadi mungkin.

Pengadilan Tinggi memutuskan Betamax pada 1984. Pada putusan 5-4, Pengadilan menyatakan bahwa Sony tidak bertanggung jawab atas pelanggaran Hak Cipta sekunder karena Beta adalah sebuah "pasal perdagangan" yang "berkuasa atas penggunaan substansial non-pelanggaran". Pengadilan selanjutnya berpendapat bahwa konsumen yang merekam acara televisi untuk memutarnya kembali nanti ("pergeseran-waktu") terlibat pada "penggunaan yang wajar" yang sah, meskipun penyalinan tidak diizinkan oleh pemilik Hak Cipta. Meskipun putusan tersebut merupakan putusan yang sempit, Betamax jauh dari konsekuensi hukum. Doktrin "penggunaan substansial non-pelanggaran" sekarang telah menjadi standar yang digunakan untuk menilai teknologi dan produk yang berpotensi melanggar.

\footnotetext{
${ }^{7}$ Seluruh uraian kasus ini merupakan diambil dan diterjemahkan dari sumber tulisan Ryan Roemer," The Digital Evolution: Freenet and the Future of Copyright on the Internet, T.T.P., T.P.,T.T.
} 
Kasus A \& M Records, Inc v. Napster, Inc (selanjutnya disebut "Napster")8

Pada 1999, keberhasilan populer pada Napster membawanya pada gugatan cepat terhadap layanan pertukaran file di A \& M Records, Inc v. Napster, Inc (selanjutnya disebut "Napster"). Industri rekaman menduga bahwa sebagian besar dari file MP3 yang diperdagangkan oleh jutaan pengguna Napster merupakan salinan tidak sah. Napster menanggapi dengan beberapa doktrin di mana kegiatan yang didukung Napster tersebut dapat dibela. Kedua pengadilan negeri dan Ninth Circuit berpihak pada industri rekaman. Napster berpendapat bahwa tindakan para penggunanya dalam bertukar file yang dilindungi penggunaan yang wajar di bawah doktrin bahwa pengguna Napster terlibat dalam "pergeseran-ruang" musik mereka dari CD ke komputer, perangkat, dll dengan cara yang sama dengan pengguna Betamax untuk "pergeseran-waktu" program televisi. 60 Ninth Circuit menyimpulkan bahwa pembelaan "pergeseran" hanya tersedia di mana teknologi "tidak sekaligus melibatkan distribusi materi berhak cipta kepada masyarakat umum. Pergeseranwaktu atau ruang materi berhak cipta hanya dilindungi ketika pada dasarnya dilakukan untuk penggunaan pribadi". Napster dikenakan kewajiban sumbangan hak cipta, karena hal tersebut diketahui, dan secara materi berkontribusi terhadap pelanggaran hak cipta penggunanya. Napster berpendapat bahwa doktrin "penggunaan substansial non-pelanggaran" Betamax melindungi mereka dari kewajiban sumbangan hak cipta. 63 Ninth Circuit mempertimbangkan kemungkinan "kemampuan" non-pelanggaran Napster, tetapi menyimpulkan bahwa doktrin tersebut tidak dapat dikenakan pada Napster karena mereka menyadari dan memiliki pengetahuan mengenai pelanggaran. Pengadilan juga menemukan bahwa Napster secara materi berkontribusi pada pelanggaran hak cipta dengan menyediakan perangkat lunak dan server pusat.65 Demikian, pengadilan mendukung perintah pengadilan kepada penggugat untuk klaim kewajiban sumbangan mereka.

Napster juga dikenakan kewajiban hak cipta perwakilan, karena Napster "memiliki hak dan kemampuan untuk mengawasi kegiatan yang melanggar dan juga memiliki kepentingan keuangan langsung dalam kegiatan tersebut." Ninth 
Circuit menemukan bahwa model bisnis Napster tergantung pada penarikan minat basis pengguna yang besar untuk memperoleh pendapatan. Dengan demikian, musik bajakan yang tersedia di Napster secara langsung menguntungkan tergugat. Pengadilan kemudian memeriksa kemampuan Napster untuk mengawasi para penggunanya dan menemukan bahwa Napster cukup bisa melakukannya. Pengadilan mengamati, "Kemampuan untuk memblokir akses pelanggar pada lingkungan tertentu untuk setiap alasan apapun merupakan bukti atas hak dan kemampuan untuk mengawasi." Pengadilan menyatakan bahwa kekuasaan kepolisian Napster "harus dilakukan sampai batas yang paling penuh. Menutup mata terhadap tindak yang terdeteksi pelanggaran demi keuntungan menimbulkan kewajiban." Karena Napster tidak cukup mengawasi pengguna dan secara langsung diuntungkan secara finansial dari pelanggaran hak cipta, Ninth Circuit menyimpulkan bahwa perintah pengadilan itu telah sesuai dengan dasar kewajiban perwakilan.

\section{Kasus Morpheous dan Grokster (selanjutnya disebut teknologi "FastTrack") ${ }^{9}$}

Setelah Napster dibebani dengan perintah dari Ninth Circuit dan perkembangan layanan pertukaran-file kehilangan kilaunya, masyarakat menemukan KaZaA, Morpheous dan Grokster (selanjutnya disebut teknologi “FastTrack"), berdasarkan pada hak milik teknologi "FastTrack". Jaringan FastTrack bergantung pada sekumpulan "supernodes" untuk meyediakan daftar dan fungsi pencarian bagi pengguna (serti server pusat pada Napster lama). Tidak seperti Napster, pengguna menjalankan supernodes dan bukan perusahaan FastTrack. FastTrack mengklaim bahwa mereka tidak mengetahui apa yang terjadi di antara supernodes, karena mereka tidak mengendalikan mereka secara langsung dan semua komunikasi supernode dienkripsi. Mengikuti pendekatan yang semakin standar untuk teknologi $\mathrm{P} 2 \mathrm{P}$, rekaman, penerbitan musik dan film industri mengajukan gugatan terhadap perusahaan yang bertanggung jawab untuk KaZaA, Morpheus, Grokster dan FastTrack pada tahun 2001 (selanjutnya disebut litigasi "Grokster"). Meskipun gugatan Grokster masih dalam tahap awal di saat penelitian ini ditulis, pengajuan dan mosi dari kedua belah pihak memberikan indikasi yang baik pertarungan 
hukum pada akhirnya. Para pihak telah mengajukan berbagai mosi dan tanggapan. Pada Desember 2002, kedua belah pihak mengajukan pendapat terkait ringkasan mosi pertimbangan di pengadilan federal, dengan harapan menang sebelum kasus benar-benar diajukan ke pengadilan. Industri konten mengklaim bahwa keuntungan tergugat Grokster dari pelanggaran hak cipta oleh pengguna seperti Napster, dan menuntut untuk kedua tanggung jawab sumbangan dan tanggung jawab perwakilan atas hak cipta. Para penggugat menyatakan bahwa tergugat FastTrack memiliki pengetahuan aktual terkait pelanggaran oleh pengguna dan bahwa mereka secara aktif mendorong masyarakat untuk memperdagangkan karya cipta yang tidak sah. Para penggugat selanjutnya berpendapat bahwa tergugat mengontrol pelanggaran hak cipta oleh pengguna karena mereka memiliki hak untuk secara sepihak mengakhiri akun pengguna. Yang terakhir, para penggugat berpendapat bahwa terdakwa telah diberikan keuntungan finansial dari pelanggaran hak cipta industri konten.

Mosi dari tergugat Streamcast untuk sebagian ringkasan pertimbangan menunjuk pada argumen terkuat tergugat Grokster terhadap kewajiban hak cipta sekunder di bawah Napster: pertama, tergugat menjalankan jaringan yang mampu melindungi "penggunaan substansial non-pelanggaran" oleh Betamax, dan kedua, tergugat tidak menjaga database pusat untuk file yang tersedia seperti Napster.

StreamCast awalnya mencatat bahwa jaringan Morpheus memiliki beberapa penggunaan non-pelanggaran, memanfaatkan fakta bahwa Morpheus memungkinkan pertukaran jenis dokumen apapun (sebagai kebalikan di Napster yang hanya menyediakan MP3). Salah satu penggunaan non-pelanggaran Morpheus adalah distribusi Proyek Gutenberg dari domain publik yakni "eBook." Penggunaan lainnya dari jaringan Morpheus adalah ketersediaan dokumen pemerintah. Ketiga, pemilik hak cipta memanfaatkan Morpheus untuk mendistribusikan media yang sah dan dilindungi. Yang terakhir, Morpheus memungkinkan pertukaran resmi demonstrasi, shareware dan freeware perangkat lunak komputer. Selain itu, StreamCast menyimpulkan bahwa jika sistem Morpheus tidak bisa memanfaatkan pembelaan Betamax (pembelaan "pasal pokok perdagangan"), maka kewajiban harus mencakup kebanyakan teknologi internet pada umumnya (seperti server web, e-mail, program FTP, dll.). Sebaliknya, 
industri konten berpendapat bahwa penggunaan "sah" ini tidak substansial dalam menghadapi pembajakan luas dan yang paling sering file tersebut tidak bisa ditemukan pada jaringan tergugat.

StreamCast juga berpendapat bahwa karena Streamcast tidak mengoperasikan file server-indeks utama, Ia bisa melarikan diri dari tanggung jawab yang dikenakan pada Napster. Sejak jaringan FastTrack mengandalkan sercontrolled "supernodes" untuk pengindeksan file, Grokster mempertahankan kontrol atas jaringan atau supernodes. Selain itu, StreamCast mengamati, "Jika [StreamCast] berhenti beroperasi, atau jika server yang menjadi tidak beroperasi... fungsi pencarian, pengindeksan, mentransfer, download [dan lainnya]... Akan terus terpengaruh." Industri konten membantah bahwa Grokster mempertahankan kontrol dan pengetahuan tentang konten di jaringan mereka. Awalnya, program Morpheus dapat mengenali dan menentukan file yang sama, yang berarti filter dapat digunakan untuk melarang download karya cipta. Selain itu, StreamCast melakukan update secara teratur perangkat lunaknya, mengirim promosi dan informasi lainnya, dan memantau papan pengumumannya dari lokasi pusat. Akhirnya, bahasa lisensi pengguna akhir Morpheus membuktikan bahwa "Morpheus adalah, layanan interaktif berkelanjutan yang [StreamCast] dapat menghentikan setiap saat."

StreamCast berpendapat bahwa untuk sebuah produk dapat menghindari kewajiban hak cipta sekunder di bawah Betamax, produk tersebut "hanya mampu dalam penggunaan substansial non-pelanggaran." Stream Cast berpendapat bahwa "kemampuan" adalah inti dari apa yang dipegang oleh Mahkamah Agung, dan bukan jumlah atau tingkat pelanggaran hak cipta yang sebenarnya. Jadi, StreamCast menyimpulkan produk tersebut akan dilindungi karena "perangkat lunak Morpheus mampu dalam penggunaan substansial non-pelanggaran pada masa sekarang dan masa masa yang akan datang." Para penggugat yakni industri konten menjawab bahwa penggunaan tersebut tidak signifikan karena mayoritas file yang diperdagangkan di jaringan FastTrack merupakan salinan ilegal dari karya cipta. Selain itu, karena Grokster memiliki pengetahuan aktual pelanggaran dan sistem FastTrack dirancang semata-mata untuk menghindari kewajiban hak cipta, pembelaan tidak tersedia. 
Beralih ke keputusan Napster, StreamCast berpendapat bahwa Ninth Circuit hanya memegang Napster, Inc. bertanggung jawab atas tindakannya, dan bukan karena arsitekturnya.109 Karena StreamCast tidak memiliki pengetahuan file yang diindeks di supernodes dan tidak 'menjalankan' jaringan pengguna Morpheus," perbedaan arsitektural ini menghalangi kewajiban hak cipta pada Napster. Industri konten menjawab bahwa Napster menghalangi setiap pembelaan Betamax karena pengetahuan aktual dan kontrol. Distrik Sentral California menolak mosi StreamCast dan kasus ini ditetapkan untuk diajukan ke pengadilan. Meskipun demikian, argumen ini tentu memberikan indikasi kuat untuk mendefinisikan masalah hukum ke dalam tahap uji coba. Selain itu, pendekatan StreamCast ini memberikan wawasan ke dalam pergeseran lanskap lingkup hukum yang mengembangkan teknologi file-sharing. Proyek P2P, seperti Freenet, sadar akan dasar hukum yang lemah di mana mereka bekerja, dan telah disesuaikan dengan putusan Napster. Hasil dari litigasi Grokster kemungkinan akan lebih mempengaruhi desain pendekatan hukum- menentang teknologi P2P.

\section{Perlindungan Hak Cipta di Internet: dari Dunia Nyata hingga Dunia Maya}

Fenomena dan kasus-kasus hak cipta di internet, pada kenyataannya telah mendorong adanya perkembangan konsepsi perlindungan hak cipta dari perlindungan hak cipta di dunia nyata bergeser ke dunia maya. Sebagaimana diketahui, sejarah perkembangan hak cipta secara modern ditandai dengan lahirnya Statuta of Anne 1710. Konsep hak cipta merupakan suatu bentuk perlindungan hukum atas karya seni, sastra dan ilmu pengetahuan. Konsep hak cipta ini telah berkembang cukup lama. ${ }^{10}$ Dari segi sejarahnya, konsepsi perlindungan ini di mulai tumbuh dengan jelas sejak ditemukannya mesin cetak pada abad pertengahan, di Eropa. Kebutuhan ini timbul karena dengan mesin cetak, karya-karya cipta dengan mudah diperbanyak secara mekanikal. Inilah yang pada awalnya menumbuhkan copyrights. ${ }^{11}$

\footnotetext{
10 Sejarah perkembangan hak cipta ini telah dimulai sejak ditemukannya mesin percetakan pada 1476 oleh Caxton di Westminster. Secara lengkap dapat dilihat pada Sam Ricketson dan Megan Richardson, Intellectual Property Cases, Material, Commentary $2^{\text {nd }}$ Edition, Butterworths, Sydney, 1998, hlm. 56-58.

${ }^{11}$ Bambang Kesowo, "Pengantar Umum Mengenai Hak Atas Kekayaan Intelektual (HAKI) di Indonesia," Disajikan dalam Pelatihan Tehnis Yustisial Peningkatan Pengetabuan Hukum bagi Wakil Ketua/ Hakim Tinggi se Indonesia yang diselenggarakan oleh Mahkamah Agung tanggal 13 s/d 17 Juni 1995 dan 20 s/d 24 Juni 1995 di Semarang, hlm. 13-14. UU Hak cipta yang pertama hanya bertujuan mencegah orang membuat salinan untuk suatu karya
} 
Dalam perkembangan selanjutnya, isi dan lingkup perlindungan hukum tersebut memperoleh kritik yang keras. Sebab, yang dianggap menikmati perlindungan hanyalah pengusaha percetakan dan penerbitan. Sedangkan pencipta karya cipta itu sendiri (authors) praktis tidak memperoleh perlindungan yang semestinya. Para filsuf Eropa yang mempelopori kritik tersebut menggunakan argumentasi bahwa karya-karya cipta pada dasarnya merupakan refleksi pribadi atau alter-ego daripada penciptanya. Kemudian tumbuhlah konsep baru author rights dan bukannya copyright. Itu pula sebabnya, ketika Belanda hadir di Indonesia dan memberlakukan aturan Hak Cipta yang disebut auterswet. ${ }^{12}$ Di Amerika Serikat sejarah perkembangan hak cipta meliputi tiga wilayah utama, yakni; Pertama, pengadopsian di dalam konstitusi dan statuta hak cipta pertama pada 1790; Kedua, statuta hak cipta 1909 dan Ketiga, statuta hak cipta 1976.13

Konsep hak cipta sendiri jika dilihat dari sistem hukum menjadi sangat menarik. Hal itu dikarenakan sistem hukum memberikan pengaruh atas konsep hak cipta. Sebagaimana diketahui di dunia ini dikenal dua sistem hukum besar, yakni sistem hukum kontinental (civil law system) dan sistem hukum anglo saxon (common law system). Dalam common law system masalah pengaturan hak cipta dilatar belakangi oleh rasionalitas ekonomi, yaitu kebutuhan untuk memberi insentif bagi penerbit yang telah mengorbankan waktu, tenaga, dan biaya serta

cetak. Para penerbit The Seasons, ciptaan penyair terkenal abad ke-18, James Thomson, selalu menggugat lewat pengadilan setiap kali ada pihak-pihak lain yang menerbitkan, tanpa izin, puisi yang termasyur itu dalam bentukbentuk yang lain, atau membajaknya, karena mereka memegang hak cipta atas karya itu, yang mereka peroleh dari Thomson. Sejak petengahan abad ke-19, cakupan hak cipta bertambah luas. Lihat Paul Goldstein, Hak Cipta: Dulu, Kini dan Esok, Yayasan Obor Indonesia, Jakarta, 1997, hlm. 4.

12 Bambang Kesowo, Op., Cit., hlm. 14.

${ }^{13}$ Konsitusi Amerika Serikat yang disahkan oleh Kongres menetapkan hukum hak cipta untuk menjamin hak eksklusif pencipta atas karya tulis mereka dengan suatu pembatasan waktu yang bertujuan mendorong kemajuan ilmu pengetahuan (progress of science). Pada tahun 1790, untuk pertama kali Kongres menetapkan suatu statuta yang memperluas perlindungan hak cipta kepada maps, charts dan buku. Sejarah hukum hak cipta telah menjadi salah satu perluasan gradual dari bentuk-bentuk karya yang dilindungi. Pada tahun 1909, Kongres menetapkan hukum hak cipta baru yang komprehensif. Section 4 menetapkan bahwa "karya-karya hak cipta yang akan dijamin di bawah undang-undang ini mencakup semua karya tertulis dari pencipta. Dengan adanya hal seperti ini telah identif dengan konstitusi. Hal ini juga dapat dinyatakan bahwa Kongres telah memperluas perlindungan hak cipta sebagaimana Konstitusi memberikan perlindungan yang luas juga. Hal ini sekaligus mengakui bahwa statutory mendefinisikan tulisan yang dapat dilindungi sejalan dengan definisi konstitusional dan hal itu dapat berupa karya seperti, rekaman suara (sound recordings). Pada tahun 1976, kongres menempatkan kembali UU Hak Cipta tahun 1909 dengan ketentuan hak cipta baru, yang mana efektif pada tanggal 1 Januari 1978. Ada dua hal yang berubah secara fundamental dalam hukum hak cipta ini, yakni; Pertama, undang-undang ini memperluas pada perlindungan karya-karya yang tidak terpublikasikan disamakan dengan karya yang dipublikasikan; Kedua, undangundang hak cipta menetapkan perlindungan untuk seumur hidup plus lima puluh tahun setelah penciptanya meninggal dunia. Donal S. Chisum dan Michael A. Jacobs, Understanding Intellectual Property Law, Matthew Bender \& Co. Inc, New York, 1992, hlm. 4-7 dan 4-9. 
mengambil resiko kerugian dalam memasarkan produk cetakannya. ${ }^{14}$ Civil Law System pengembangan pengaturan hak cipta ditumpukan pada konsep kekayaan yang merupakan manifestasi dan eksistensi pencipta. Dalam kaitan ini sebuah karya cipta dianggap sebagai perwujudan dari kepribadian pencipta atau personality. 15

Adanya rasionalitas yang berbeda dalam dua sistem hukum ini berkaitan dengan perlindungan hak cipta lambat laun keduanya saling mempengaruhi. Civil law system mempengaruhi common law system dan sebaliknya. Pengaruh dari kedua sistem ini terasa manakala hak cipta dibawa pada lingkup internasional. Dari konteks internasional ini, maka diharmonisasikan ke dalam hukum hak cipta negara-negara yang menganut civil law system maupun anglo saxon system.

Kini, sejarah hak cipta di era digital mengalami suatu perkembangan yang sangat pesat. Tantangan hak cipta tidak lagi dihadapkan kepada persoalan sistem hukum yang dianut, namun terkait juga dengan karakteristik dari teknologi internet sebagai ciri dari era digital tersebut. Pada Desember 1996, World Intellectual Property Organization (WIPO) menyelenggarakan konferensi diplomatik di Jenewa untuk mempertimbangkan proposal untuk memperbarui norma kekayaan intelektual internasional dalam hubungannya dengan perubahan digital environment. Konfrensi Diplomatik ini WIPO mengundang 160 negara untuk membahas modifikasi norma konvensional dan menjadikan norma baru dalam mengatur masalah hak kekayaan intelektual, khususnya hak cipta. Lingkup yang diusulkan untuk dimodifikasi yakni, kreasi, adopsi, transmisi dan distribusi karya melalui medium digital.

Pada akhirnya, hasil dari konfrensi diplomatik ini melahirkan WIPO Copyright Treaty dan WIPO Performance and Phonograms Treaty yang dikenal dengan istilah WIPO Internet Treaties yang ditandatangani dan memiliki kekuatan mengikat sejak 2002. WIPO Internet Treaties telah telah mendorong adanya pergeseran konsep hak cipta yang semula, hanya difokuskan untuk karya seni, sastra dan ilmu pengetahuan dalam konteks di dunia nyata, memperluas cakupan dan lingkup hak cipta ke medium digital.

\footnotetext{
${ }^{14}$ Henry Sulistiyo Budi, Hak Cipta Tanpa Hak Moral, Rajawali, Jakarta, 2011, hlm. 23.

${ }^{15}$ Ibid., hlm. 27.
} 
Simon Fitzpatrick menyatakan bahwa kehadiran WIPO Internet Treaties sangat penting bagi pengembangan hukum hak cipta di cyberspace. Menurutnya, ada lima prinsip dasar dari diterapkannya hak cipta melalui WIPO Internet Treaties di cyberspace, yakni; Pertama, WIPO Internet Treaties secara tegas menyatakan bahwa hak reproduksi di dalam Article 9 Konvensi Berne diberlakukan juga untuk lingkungan digital; Kedua, norma diadaptasi dengan familier ke dalam hak penyiaran dan difusi suatu hak tunggal yang layak untuk lingkungan pemusatan media; Ketiga, norma diperbolehkan untuk diperluas dalam batasan lingkungan digital, dan pengecualian dalam hukum nasional harus dapat diterima dalam Konvensi Berne; Keempat, norma mempersyaratkan ganti kerugian hukum yang layak dan efektif untuk perlindungan teknologi yang digunakan oleh pemegang hak cipta; dan Kelima, norma memberikan mandat untuk menetapkan ganti rugi yang layak dan efektif atas percobaan mengalihkan hak manajemen informasi atau menyetujui perbanyakan karya dimana telah dialihkan dan dirusak hak manajemen informasi mereka. ${ }^{16}$

Dalam perkembangannya, setelah dilahirkannya dan ditandatanganinya WIPO Internet Treaties, maka beberapa mulai melakukan harmonisasi hukum hak cipta mereka, untuk disesuaikan dengan konvensi hak cipta internasional tersebut. Amerika Serikat merupakan negara yang paling awal melakukan harmonisasi atas WIPO Internet Treaties yang dituangkan ke dalam the Digital Millennium Copyright Act ("DMCA") pada 1998. DMCA ini memiliki arti yang sangat penting dikarenakan Amerika Serikat secara agresif selalu mendorong adanya standar yang sama dalam kesepakatan perdagangan bebas baik bilateral atau regional di negara-negara lain. ${ }^{17}$

Negara lainnya adalah Jepang. Jepang telah melakukan harmonisasi hukum hak cipta dari WIPO Internet Treaties ke dalam The Copyright Act (Law 48, 1970). Beberapa hal yang telah diharmonisasi itu meliputi: 1. Establishment of penal sanctions against circumvention of technological protection measure; 2. Infrangement liability imposed on persons who have erased or altered rights management information; 3.

${ }^{16}$ Simon Fitzpatrick, "Prospect of Further Copyright Harmonization," European Intellectual Property Review, 2003, hlm. 4.

${ }^{17}$ Peter K. Yu, "Digital Piracy and The Copyright Response," This Chapter was adapted and revised from the Author's earlier works concerning copyright law in the digital environment, hlm. 4-5. 
Establishment of the right of assignment for authors, performers and producers of phonograms; 4. Establishment of the right of screening for alla categories fo works; 5 . Abolition of transtional measure for public performance of recorded music. ${ }^{18}$

Sementara itu, di New Zealand harmonisasi WIPO Internet Treaties ke dalam Copyright Act 1994 saat ini telah sampai pada tingkat usulan-usulan. Salah satu usulan yang menarik seperti dikemukakan oleh New Zealand's Ministry of Economic Development. Beberapa usulan perubahan atas Copyright Act 1994 meliputi pada; The Reproduction Right, The Communication Right, Liability of Internet Service Provider (ISPs), Technological Protection Measure (TPMs) dan Electronic Right Management Information (ERMI). 19

\section{Hukum dan Teknologi: Model Kolaborasi Hukum dan Teknologi dalam Kerangka Perlindungan Hak Cipta di Internet}

Internet sebagai sebuah temuan teknologi pada Abad 21 ini merupakan sesuatu hal yang sangat luar biasa. Internet membuat umat manusia di seluruh dunia dapat melakukan komunikasi lintas batas tanpa suatu hambatan yang berarti. Hal ini berbeda ketika komunikasi tersebut dilakukan secara fisik. Hadirnya teknologi internet ini ternyata telah mendorong perubahan sikap dan perilaku manusia. Hal mana manusia dengan difasilitasi teknologi ini ada kecenderungan melakukan tindakan-tindakan di luar batas kewajarannya sebagai manusia. Di samping itu, terkadang melalui pemanfaatan teknologi internet ini, manusia menjadi berlaku sewenang-wenang terhadap hak-hak orang lain, bahkan dapat dimaknai melanggar hukum dalam perspektif hukum konvensional.

Salah satu sikap dan perilaku manusia yang berubah itu adalah berhubungan dengan penggunaan atau pemanfaatan berbagai informasi yang tersedia di internet. Sebagaimana diketahui, di internet tersedia berbagai informasi. Informasi ini terkadang masuk rumusan atau kualifikasi hasil olah fikir manusia yang dilindungi oleh hukum. Contohnya, tulisan yang berbentuk elektronik, gambar, grafik, logo dagang, domain name yang kesemuanya berbentuk elektronik.

\footnotetext{
18 Taruo Doi,'Japan Copyright - Amandement of The Copyright Act to Implement WIPO Treaties and for Other Purposes," European Intellectual Property Review, 2000.

${ }^{19}$ John Smillie, "Digital Copyright Reform in New Zealand," Eropean Intellectual Property Review, 2004.
} 
Dalam realitasnya informasi dalam jenis ini acapkali disalahgunakan dalam bentuk di-copy, ditransmisikan, didistribusikan dan diumumkan dengan "klaim" seolah-olah informasi tersebut dimiliki olehnya. Hal yang sangat fatal manakala tindakan tersebut akhirnya menimbulkan kasus. Hal ini sebagaimana diungkapan pada tulisan sebelumnya. Akibatnya, banyak kreator atau penghasil informasi elektronik dalam jenis ini merasa resah dan khawatir apabila perbuatan tersebut terus-terusan dilakukan, maka akan mematikan berbagai kreativitas yang selama ini ada di internet.

Oleh sebab itu, maka berbagai cara atau solusi diupayakan untuk dapat meminimalisir tindakan dari pengguna internet. Adapun cara-cara yang dilakukan, misalnya melalui pendekatan penerapan hukum konvensional. Di mana perbuatan di atas dicoba diselesaikan melalui penegakan hukum konvensional. Pada kenyataannya, hal ini ada yang berhasil dan ada juga yang tidak mengingat internet memiliki karakteristik yang berbeda dengan dunia nyata. Kemudian, cara lainnya yang dilakukan melalui pendekatan teknologi. Pendekatan teknologi dipilih karena dengan penerapan teknologi, maka berbagai tindakan/perbuatan yang merugikan orang lain dapat dicegah. Namun, ternyata teknologi sendiri tidak mampu menjalankan fungsinya secara penuh mengingat teknologi senantiasa memiliki keterbatasan. Maka, pada akhirnya ditempuhlah cara berikutnya yaitu model kolaborasi antara hukum dan teknologi.

Model pengkolaborasian hukum dan teknologi dimaksudkan untuk dapat memberikan suatu sistem perlindungan hukum yang efektif. Fungsi pencegahan dan penindakan akan menjadi lebih kuat dan baik apabila hukum dan teknologi dikolaborasikan dalam suatu tindakan/perbuatan yang melanggar hak orang lain di internet. Di samping itu, melalui kolaborasi hukum dan teknologi hak-hak orang yang dilanggar dapat dipulihkan sebagaimana seharusnya. Misalnya, hak untuk mendapatkan pembayaran atas penggunaan informasi yang telah di buat.

Secara internasional model kolaborasi hukum dan teknologi tidak hanya dilihat secara konseptual, namun hal ini telah direalisasikan dan menjadi kesepakatan global. Hal ini dapat ditemukan pada konvensi internasional hak cipta yang dikenal dengan istilah WIPO Internet Treaties, yang mencakup dua konvensi internasional, yakni; WIPO Copyright Treaty dan WIPO Performence and Phonogram 
Treaty. Adapun ketentuan yang dirujuk adalah Article 11 WCT yang selengkapnya berbunyi:

The provision on technological measures obliges the Contracting Parties to provide adequate legal protection and effective legal remedies against the circumvention of effective technological measures that are used by authors in connection with the exercise of their rights under this Treaty or the Berne Convention and that restrict acts, in respect of their works, which are not authorized by the authors concerned or permitted by law.(Garis bawah dari penulis).

Article. 18 WPPT yang selengkapnya berbunyi:

Contracting Parties shall provide adequate legal protection and effective legal remedies against the circumvention of effective technological measures that are used by performers or producers of phonograms in connection with the exercise of their rights under this Treaty and that restrict acts, in respect of their performances or phonograms, which are not authorized by the performers or the producers of phonograms concerned or permitted by law. (Garis bawah dari penulis)

Dari dua ketentuan di atas, maka jelas bahwa perlindungan teknis menjadi bagian yang tidak terpisahkan dari pengaturan hak cipta secara internasional. Pengaturan perlindungan teknis ini dimaksudkan untuk perlindungan hak cipta di internet yang efektif. Ada dua kewajiban yang timbul dari dua di atas, yakni; Pertama, negara berkewajiban untuk memberikan perlindungan hukum yang memadai, dan ganti kerugian yang efektif, terhadap pengelakan dari tindakan teknologi, seperti sistem akses bersyarat dan enkripsi yang digunakan oleh pemegang hak cipta untuk melindungi karya mereka; Kedua, negara berkewajiban untuk memberikan pengamanan teknologi yang memiliki keandalan dan integritas di pasar online oleh negara-negara yang membutuhkan untuk melarang perubahan yang disengaja, atau penghapusan, informasi elektronik, yang menyertai materi yang dilindungi, dan yang mengidentifikasi pekerjaan, pemilik hak, dan syarat dan ketentuan untuk penggunaannya. ${ }^{20}$

Amerika Serikat sebagai negara yang telah mengimplementasikan WIPO Internet Treaties, telah memformulasikan model kolaborasi teknologi dan hukum yang tertuang di dalam ketentuan Pasal 103 Digital Millenium Copyright Act (DMCA)1998 pada Bab 1201 mengatur mengenai kewajiban pemilik hak cipta

${ }^{20}$ Denise Rosemary Nicholson, "Digital Rights Management and Access to Information: a developing country's perspective," Library and Information Science Research Electronic Journal Volume 19, Issue 1, March 2009, hlm. 3 . 
dalam menyediakan teknologi pengaman yang memadai dan efektif pada karya ciptanya, untuk menangkal perusakan terhadap teknologi pengaman yang mereka gunakan. ${ }^{21}$ Bab 1202 membagi pengaturan terkait teknologi pengaman menjadi 2 kategori yaitu:22 Pertama, tindakan yang mencegah akses yang tidak sah pada karya yang dilindungi hak cipta; dan Kedua, tindakan yang mencegah penyalinan yang tidak sah atas karya dilindungi hak cipta. Pembagian kategori pemberian teknologi pengaman tersebut digunakan untuk memastikan bahwa masyarakat akan memiliki kemampuan yang berkelanjutan dalam penggunaan wajar pada karya yang dilindungi hak cipta.

DMCA 1998 juga memberikan pengaturan tentang sanksi yang dapat dikenakan kepada para pihak yang melakukan pengursakan teknologi pengaman. Pelanggaran atas perusakan terhadap teknologi pengaman yang diatur di dalam Bagian 1201-1202 dapat diajukan gugatan perdata ke Pengadilan Federal. ${ }^{23}$

Sejalan dengan langkah Amerika Serikat yang telah menginsiasi perlindungan hak cipta di internet melalui model kolaborasi teknologi dan hukum di dalam DMCA 1998, maka beberapa negara lainnya mulai melakukan hal yang sama, terutama, negara-negara yang telah meratifikasi WIPO Internet Treaties. Hal ini tidak terkecuali Indonesia. Indonesia sebagai negara yang telah meratifikasi WIPO Internet Treaties telah mulai melakukan perlindungan hak cipta di internet melalui model kolaborasi teknologi dan hukum semenjak dibentuknya ketentuan UU No. 19 Tahun 2002 tentang Hak Cipta. Hal ini sebagaimana yang tertuang di dalam ketentuan Pasal 25, 27 dan 72 UU No. 19 Tahun 2002. Pasal 25 ayat (1) dan (2) Undang-Undang No. 19 Tahun 2002 menyatakan“ (1) Informasi elektronik tentang informasi manajemen hak Pencipta tidak boleh ditiadakan atau diubah;" "(2) Ketentuan lebih lanjut sebagaimana dimaksud pada ayat (1) diatur dengan Peraturan Pemerintah."

Pasal 25 ayat (1) dan (2) Undang-Undang No. 19 Tahun 2002 berisi norma mengenai informasi manajemen hak pencipta. Adapun yang dimaksud dengan informasi manajemen hak pencipta berdasarkan penjelasan Pasal 25 UndangUndang Hak Cipta ialah informasi yang melekat secara elektronik pada suatu

21 The Digital Millenium Copyright Act of 1998, U.S. Copyright Office Summary, December 1998, hlm. 3.

${ }^{22}$ Ibid, hlm. 3-4.

${ }^{23}$ Ibid, hlm. 7. 
ciptaan atau muncul dalam hubungan dengan kegiatan pengumuman yang menerangkan tentang suatu Ciptaan, Pencipta dan kepemilikan hak maupun informasi persyaratan penggunaan, nomor atau kode informasi. Intinya Informasi manajemen hak pencipta secara teknis merupakan suatu teknologi pengaman yang tujuannya memberikan informasi terkait dengan kepemilikan hak cipta dan dimaksudkan untuk memberikan perlindungan teknis atas kepemilikan hak cipta dari pencipta.

Selanjutnya, Pasal 27 Undang-Undang No. 19 Tahun 2002 menyatakan: "Kecuali atas izin Pencipta, sarana kontrol teknologi sebagai pengaman hak Pencipta tidak diperbolehkan dirusak, ditiadakan, atau dibuat tidak berfungsi." Penjelasan Pasal 27 Undang-Undang No. 19 Tahun 2002 secara tersirat menyatakan bahwa sarana kontrol teknologi yang dipahami di antaranya mencakup kode rahasia, password, bar code, serial number, teknologi deskripsi (descryption) dan enkripsi (encryption) yang digunakan untuk melindungi ciptaan. Selengkapnya Pasal 72 ayat (7) dan (8) Undang-Undang No. 19 Tahun 2002 berbunyi:

(7)Barangsiapa dengan sengaja dan tanpa hak melanggar Pasal 25 dipidana dengan pidana penjara paling lama 2 (dua) tahun dan/atau denda paling banyak Rp 150.000.000,00 (seratus lima puluh juta rupiah). (garis bawah Penulis).

(8)Barangsiapa dengan sengaja dan tanpa hak melanggar Pasal 27 dipidana dengan pidana penjara paling lama 2 (dua) tahun dan/atau denda paling banyak Rp 150.000.000,00 (seratus lima puluh juta rupiah). (garis bawah Penulis).

Dalam perkembangannya, ketika Undang-Undang No. 19 Tahun 2002 diganti dengan Undang-Undang No. 28 Tahun 2014, kolaborasi teknologi dan hukum di dalam ketentuan Undang-Undang No. 28 Tahun 2014 terus dipertahankan dalam rangka perlindungan hak cipta di internet. Hal ini disebutkan dalam Pasal 6, 7, 52, 53 dan 112 Undang-Undang No. 28 Tahun 2014. Di dalam ketentuan Pasal 6 dan 7 UU No. 28 Tahun 2014 lebih dititikberatkan teknologi sebagai perlindungan hak cipta atas hak moral. Anggapan ini dapat dilihat pada bunyi Pasal 6 UndangUndang No. 28 Tahun 2014 menyatakan: "Untuk melindungi hak moral sebagaimana dimaksud dalam Pasal 5 ayat (1), Pencipta dapat memiliki: a. informasi manajemen Hak Cipta; dan/atau b. informasi elektronik Hak Cipta." Sementara, Pasal 7 ayat (1), (2), (3) 
Undang-Undang No. 28 Tahun 2014 menyatakan: (1) Informasi manajemen Hak Cipta sebagaimana dimaksud dalam Pasal 6 huruf a meliputi informasi tentang:a. metode atau sistem yang dapat mengidentifikasi originalitas substansi Ciptaan dan Penciptanya; dan $b$. kode informasi dan kode akses. (2) Informasi elektronik Hak Cipta sebagaimana dimaksud dalam Pasal 6 huruf b meliputi informasi tentang: a. suatu Ciptaan, yang muncul dan melekat secara elektronik dalam hubungan dengan kegiatan Pengumuman Ciptaan; b. nama pencipta, aliasnya atau nama samarannya; c. Pencipta sebagai Pemegang Hak Cipta;d. masa dan kondisi penggunaan Ciptaan;e. nomor; dan f. kode informasi. (3) Informasi manajemen Hak Cipta sebagaimana dimaksud pada ayat (1) dan informasi elektronik Hak Cipta sebagaimana dimaksud pada ayat (2) yang dimiliki Pencipta dilarang dihilangkan, diubah, atau dirusak.

Pengaturan teknologi yang terdapat di dalam Pasal 7 ayat (3) UU No. 28 Tahun 2014 diperkuat lagi dengan memberikan sanksi pidana. Hal ini sebagaimana tertuang di dalam Pasal 112 Undang-Undang No. 28 Tahun 2014 yang berbunyi:

Setiap Orang yang dengan tanpa hak melakukan perbuatan sebagaimana dimaksud dalam Pasal 7 ayat (3) dan/atau Pasal 52 untuk Penggunaan Secara Komersial, dipidana dengan pidana penjara paling lama 2 (dua) tahun dan / atau pidana denda paling banyak Rp. 300.000.000,00 (tiga ratus juta rupiah).

Akan tetapi keberadaan sanksi pidana ini, jika merujuk pada ketentuan Pasal 120 Undang-Undang No. 28 Tahun 2014 sebagai delik aduan, kedudukannya menjadi sangat tidak kuat dalam melindungi teknologi. Dalam hal teknologi yang digunakan untuk perlindungan hak cipta atas hak ekonomi tertuang di dalam Pasal 52 UU No. 28 Tahun 2014. Selengkapnya bunyi Pasal 52 UU No. 28 Tahun 2014 menyatakan:

Setiap Orang dilarang merusak, memusnahkan, menghilangkan, atau membuat tidak berfungsi sarana kontrol teknologi yang digunakan sebagai pelindung Ciptaan atau produk Hak Terkait serta pengaman Hak Cipta atau Hak Terkait, kecuali untuk kepentingan pertahanan dan keamanan negara, serta sebab lain sesuai dengan ketentuan peraturan perundang-undangan, atau diperjanjikan lain.

Dalam penjelasan Pasal 52 UU No. 28 Tahun 2014 dinyatakan bahwa sarana kontrol teknologi adalah setiap teknologi, perangkat, atau komponen yang dirancang untuk mencegah atau membatasi tindakan yang tidak diizinkan oleh Pencipta, Pemegang Hak Cipta, pemilik Hak Terkait, dan/atau yang dilarang oleh 
peraturan perundang-undangan. Dalam konteks lainnya penormaan teknologi dengan tujuan perlindungan hak cipta atas hak ekonomi terdapat juga pada ketentuan Pasal 53 ayat (1) dan (2) UU No. 28 Tahun 2014 yang berbunyi: (1) Ciptaan atau produk Hak Terkait yang menggunakan sarana produksi dan/atau penyimpanan data berbasis teknologi informasi dan/atau teknologi tinggi, wajib memenuhi aturan perizinan dan persyaratan produksi yang ditetapkan oleh instansi yang berwenang. (2) Ketentuan lebih lanjut mengenai sarana produksi dan/atau penyimpanan data berbasis teknologi informasi dan/atau teknologi tinggi sebagaimana dimaksud pada ayat (1) diatur dengan Peraturan Pemerintah.

Dalam penjelasan Pasal 53 ayat (1) Undang-Undang No. 28 Tahun 2014 dinyatakan bahwa sarana produksi dan/atau penyimpanan data berbasis teknologi informasi dan/ atau teknologi tinggi antara lain cakram optik, server, komputasi awan (cloud), kode rahasia, password, barcode, serial number, teknologi dekripsi (descryption), dan enkripsi (encryption) yang digunakan untuk melindungi Ciptaan. Untuk ketentuan Pasal 52 UU No. 28 Tahun 2014 tidak diperkuat dengan sanksi pidana.

Namun demikian, dalam konteks ini UU No. 28 Tahun 2014 selain berupaya mempertahankan teknologi sebagai sarana perlindungan hak cipta sekaligus menjadi objek yang dilindungi ketentuan hak cipta Indonesia. Ketentuan UU No. 28 Tahun 2014 telah memberikan peluang untuk merusak, memusnahkan, menghilangkan, atau membuat tidak berfungsi sarana kontrol teknologi teknologi tersebut yang tidak dikualifikasikan sebagai pelanggaran hak cipta dengan alasan untuk kepentingan pertahanan dan keamanan negara, serta sebab lain sesuai dengan ketentuan perundang-undangan, atau diperjanjikan lain, di mana hal ini di dalam ketentuan UU No. 19 Tahun 2002 tidak diatur.

\section{Penutup}

Berdasarkan rumusan permasalahan dan pembahasan di atas, dapat dikemukakan tiga kesimpulan. Pertama, kehadiran internet telah membawa dampak negatif kepada sikap dan perilaku manusia. Dampak negatif ini tercerminkan dengan maraknya kasus-kasus pelanggaran hak cipta salah satunya. Dari situasi ini, maka masalah perlindungan hak cipta di internet menjadi salah satu isu yang krusial. 
Kedua, selama ini perlindungan hak cipta di internet dapat dilakukan melalui pendekatan teknologi atau pendekatan hukum. Namun, apabila pendekatan ini dilakukan secara sendiri-sendiri, maka perlindungan hak cipta di internet menjadi sangat sulit diwujudkan. Untuk dapat mewujudkan perlindungan hak cipta di internet, maka model kolaborasi antara pendekatan teknologi dan hukum menjadi suatu keniscayaan. Ketiga, instrumen perlindungan hak cipta di internet mengkolaborasikan antara pendekatan teknologi dan hokum. Hal ini dapat dilihat pada ketentuan Article 11 dan 18 WIPO Internet Treaties dan di beberapa negara lainnya, seperti Amerika Serikat dan Indonesia.

\section{Daftar Pustaka}

\section{Buku}

Budi, Henry Sulistiyo, Hak Cipta Tanpa Hak Moral, Rajawali, Jakarta, 2011.

Chisum, Donal S., dan Michael A. Jacobs, Understanding Intellectual Property Law, Matthew Bender \& Co. Inc, New York, 1992.

Djumhana, Muhamad, dan R Djubaedillah, Hak Milik Intelektual (Sejarah, Teori, dan Praktiknya di Indonesia), Citra Aditya Bakti, Bandung, 1997.

Goldstein, Paul, Hak Cipta: Dulu, Kini dan Esok, Yayasan Obor Indonesia, Jakarta, 1997.

Ricketson, Sam, dan Megan Richardson, Intellectual Property Cases, Material, Commentary 2nd Edition, Butterworths, Sydney, 1998.

Riswandi, Budi Agus, dan M Syamsudin, Hak Kekayaan Intelektual dan Budaya Hukum, Rajagrafindo Persada, Jakarta, 2005.

Roemer, Ryan," The Digital Evolution: Freenet and the Future of Copyright on the Internet, T.T.P., T.P.,T.T.

Stokes, Simon, Digital Copyrights Law and Practice, Butterworths LexisNexis, United Kingdom, 2002.

\section{Artikel Jurnal}

Burk, Dan L." The Mereology of Digital Copyright," Fordham Intell. Prop. Media \& Ent. L.J. (Vol. 18).

Doi, Taruo, "Japan Copyright - Amandement of The Copyright Act to Implement WIPO Treaties and for Other Purposes," European Intellectual Property Review, 2000.

Fitzpatrick, Simon, "Prospect of Further Copyright Harmonization," European Intellectual Property Review, 2003. 
Nicholson, Denise Rosemary, "Digital Rights Management and Access to Information: a developing country's perspective," Library and Information Science Research Electronic Journal Volume 19, Issue 1, March 2009.

Smillie, John, "Digital Copyright Reform in New Zealand," Eropean Intellectual Property Review, 2004.

Wood, Jessica A. “The Darknet: A Digital Copyright Revolution," XVI Rich. J.L. E Tech. 14 (2010), http://jolt.richmond.edu/v16i4/article14.pdf

\section{Makalah}

Arsenova, Emilija, "Technical aspects of Digital Rights Management," Seminar: Digital Rights Management.

AusAID dan ASTP II, "Indonesia Australia Specialised Training Project Phase II,"Short Course in Intellectual Property Rights (Elementry), Conducted by Asian Law Group Pty Ltd.

Kesowo, Bambang, "Pengantar Umum Mengenai Hak Atas Kekayaan Intelektual (HAKI) di Indonesia," Disajikan dalam Pelatihan Tehnis Yustisial Peningkatan Pengetahuan Hukum bagi Wakil Ketua/Hakim Tinggi se Indonesia yang diselenggarakan oleh Mahkamah Agung tanggal 13 s/d 17 Juni 1995 dan 20 s/d 24 Juni 1995 di Semarang.

\section{Peraturan Perundang-undangan}

The Digital Millenium Copyright Act of 1998, U.S. Copyright Office Summary, December 1998.

UU No. 19 Tahun 2002 tentang Hak Cipta (Lembaran Negara Republik Indonesia Tahun 2002 Nomor 85, Tambahan Lembaran Negara Republik Indonesia Nomor 4220).

UU No. 28 Tahun 2014 tentang Hak Cipta (Lembaran Negara Republik Indonesia Tahun 2014 Nomor 266, Tambahan Lembaran Negara Republik Indonesia Nomor 5599).

\section{Konvensi Internasional}

WIPO Internet Treaties, 1996.

\section{Internet}

http://www.dgip.go.id/penindakan-hak-cipta-atas-software diakses 24 Agustus 2014. 